\title{
Transnational Voyages: Reflections on Teaching Exodus to North Korea
}

\section{Adam Cathcart \\ Pacific Lutheran University}

Few courses are more difficult to teach than Modern Japan. While the myths, stereotypes, and deep sensitivities that cling to Japanese history might be held responsible for this difficulty, no less culpable are the relentlessly churning printing presses. The whole idea of "staying current" with scholarship on modern Japan, and the quest for the perfect combination of course texts, seems always out of reach and remains intimidating for scholars trained primarily in Chinese or Korean history. Naturally, reading the latest scholarship in order to lard one's lectures with new details is a joy, but preparing to teach from a completely new monograph is a different and more daunting matter. And so my colleagues can be forgiven for being dismissive when a recommendation is advanced for yet another text to read and incorporate into their syllabi on modern Japanese history. In an environment of turbulence, transformation, and controversy, not changing one's syllabus might be considered a mark of serenity and success.

In preparing the spring semester 2008 I acted against my better judgment and assigned Tessa Morris-Suzuki's Exodus to North Korea: Shadows from Japan's Cold War (Rowman $\&$ Littlefield, 2007) to a class of about twenty undergraduates at Pacific Lutheran University. Assigning the text was a somewhat impulsive act, one based upon a few blurbs, the notion that the book would fit into my course themes, and my faith in the Australian scholar's reputation and previous articles. On 
the face of it, the book appeared to be a convenient means of coasting to the end of an indeterminate semester, as well as a somewhat selfish way of gratifying my own desire to know more about North Korea. I called the campus bookstore, slapped up a page of publicity on my office door, and picked up a copy of the book to read on my own research sojourn to Northeast Asia.

As a research monograph, the text uses interview data and newly opened archives of the Red Cross Society in Geneva to argue that the Japanese government was guilty of complicity with the repatriation of some 100,000 Koreans from democratic Japan to totalitarian North Korea (the DPRK) in 1958-1960. But these research data are interwoven with a secondary storythat of the researcher herself, in a personalized meditation on her quest for historical truth in the early 21 st century. I wondered if my students would embrace, tolerate, or rebel against the text's peripheral premise in its unorthodox manner of delivery.

My experience in teaching Exodus to North Korea was both rewarding and difficult. I believe that this text contains supreme advantages that make it an ideal point of entry for modern Japan classes and student researchers in those courses. However, sheathed in these advantages are difficulties which I also wish to share. What does this book tell us about transnational East Asia? Further, how does this text uniquely illuminate what we do as scholars?

\section{Making the Case for Significance: North Korea-Japan Relations}

In teaching any book, it is a good idea to prompt students to express explicitly the significance of the topic under study. This process is especially necessary-and fun-with this book. Through discussion with my students, I came to believe that Morris-Suzuki's text was important on a number of levels:

1. The book adds depth to understanding of the problems of Koreans in Japan and the institutionalization of anti Korean sentiment in Japan. 
2. The book lends insight into the nature of the North Korean state and diversifies our view of what might before have been viewed in monolithic terms as "the North Korean people."

3. Morris-Suzuki challenges the notion of North Korea's perpetual isolationism by showing that, although Japan still lacks diplomatic relations with the DPRK, this absence of a government relationship did not prevent some extensive people-to-people relations between Japan and North Korea in the 1950s.

4. The text prompts discussion of the Japanese phobia toward North Korea today, mainly over abduction issues but also over the North Korean nuclear program. (This can be juxtaposed against the "[South] Korean Wave" which is sweeping Japan concurrently.)

5. The book invites discussion of the moral ambiguities encountered by members of Non-Governmental Organizations (NGOs) operating inside of North Korea. (This latter question is an important aspect to discuss for students considering global careers for such international organizations such as the Red Cross or the UN World Food Program.)

6. The narrative format of the text prompts discussion of the nature of history, historical research, and the method of story-telling.

Successful use of Morris-Suzuki's text in the classroom is predicated upon prior attention to the issues surrounding the Zainichi, or Korean population in Japan. I attack this problem from multiple angles in my Modern Japan course. After briefly addressing Hideyoshi's traumatic invasions of the peninsula in the 1590 s, I encapsulate the early Meiji debate over Korea as part of Japan's cordon of security. Saigo's unsuccessful arguments to his fellow genro in 1873 to invade Korea are easily tied in with a lecture on this central figure of the Satsuma Rebellion. I then spend a full day on the impacts of the SinoJapanese War and the Treaty of Shimonoseki, with readings 
assigned from James Huffman's incomparable Modern Japan: A History in Documents (Oxford, 2006) and online Historical New York Times. Students thereby gain a sense of Korea's strategic importance to Japan. The human ties between the two are more deeply engaged via a lecture on the Japanese colonization of Korea. Now that the students are primed, my first full-scale engagement with Koreans in Japan comes via an essay by ASIANetwork member Jin Hee Lee about the massacre of Koreans after the Great Kanto Earthquake of 1923. Students are asked to write a 600-word response to Dr. Lee's article. Issues of postcolonialism are then engaged through readings in John Dower's Embracing Defeat and via research in primary documents from the U.S. occupation regarding treatment of Koreans and Taiwanese as "third country nationals." As far as the syllabus is concerned, the issue of Koreans in Japan is then left dormant until arriving at MorrisSuzuki's book.

Using Exodus to North Korea was an excellent way to lend continuity to these semester-long themes, and deepened student grasp of the concept of Koreans as an important "other" in Japan. But bringing North Korea into focus as a kind of "wild card" with only $15 \%$ of the semester remaining brought another, unexpected benefit: It supercharged and reinvigorated my students by presenting North Korea to them as a new counterfoil to Japan, and lent some urgency to the end of the semester. (For instructors who see value in this technique, but wish to tackle the subject of contemporary Koreans in Japan more rapidly, a fleet alternative to Morris-Suzuki exists in the form of a manga series entitled Nambul: War Stories.)

Few countries are simultaneously as obscure and as barnacled with misperceptions as North Korea. Students are surprised to hear about the deep connections between Japan and North Korea, and none have thus far complained that Modern Japan courses should stick only to Japan. By and large, students are glad to pivot and examine a facet of Japan's foreign policy and understand better the relation of Japan with its internal population of Zainichi Koreans. 
Fortunately for scholars whose primary research areas lie outside of Japan, the transnational turn has made it more logical to focus on the breadth of Japan's foreign relations as a binding theme. Courses that allow students to see how Japan's internal development in the 20th century as linked to its colonial process can reveal also how contemporary Japan remains linked to its colonial past. Yet the Cold War witnessed the political fragmentation of the East Asian region that had previously experienced a high tide of unity "under the black umbrella" of Japanese imperialism. Now, as Asia moves toward integration, it remains to be seen if Japan's impetus will be to participate in or attempt to remain apart from this process. Japan's entanglement with, and mutual perceptions of its neighboring states constitute a significant component in determining which direction will be taken. Morris-Suzuki states that "[s]ea currents know no frontiers" (p. 54), a reference to the uncertain national status of the Koreans who came to the DPRK from Niigata, crossing the frigid Sea of Japan. Her research illustrates to our students the importance and the difficulty of intermingling transnational histories with the politics of the past in Japan.

Finally, Morris-Suzuki's unapologetic use of the personal pronoun, her conveying of her own struggles and experiences in research, and her penchant for self-inquiry caused me to reflect on my own mission as a scholar. My recent research in the Chinese Foreign Ministry Archive on Chinese attitudes toward Japan, my department's emphasis on war crimes research in World War II , and my university's connections with China and emphasis on global reconciliation-all these factors have firmly convinced me of the need to place modern Japan's "history problem" front and center in my course in various ways and, in so doing, to situate contemporary Japan within its many bilateral relationships. 